\title{
Eichler, Jessika. 2019. Reconciling indigenous peoples' individual and collective rights: participation, prior consultation and self- determination in Latin America. New York: Routledge. 196 p.
}

doi: http://dx.doi.org/10.18543/djhr.2118

The author's initial questions highlight the relationship between the collective rights of indigenous peoples and the individual rights of their members. They are pertinently related to the existence of sub-groups that are in a position of clear disadvantage and vulnerability, such as women or children.

The analysis of the relationship of these rights is done within the framework of the exercise of rights of participation, prior consultation and self-determination in Latin America, a region where large investments are promoted for the extraction of strategic natural resources in indigenous territories and where the colonial structures have not yet been diluted. In this context, it must be understood that the discourses of indigenous peoples have managed to penetrate the development of international human rights law. However, there is still a rather complicated challenge in the implementation and practice of what has been obtained at the international level.

Eichler's work is quite useful at the local level, in the implementation of international human rights standards. The reference frame is the premise that an ideal decision-making process is one in which the entire indigenous community is part of the entire process. This means that all members are not just present, but have the opportunity to receive information, to give their opinion, to be heard and to express their decision freely. However, the process is complicated even in the hypothetical case in which all members of the community have the same possibility of expression and decisionmaking capacity. The heterogeneity of indigenous communities, being composed of groups that have a greater or lesser impact on the decision-making process and on the final decision, complicates the process further.

This book offers a deep theoretical reflection enriched with an empirical investigation on the participation of excluded groups within indigenous communities. The author's approach is innovative, since it goes further than the common studies on participation rights (in the context of extractive industries) from the perspective of the collective exercise of these rights. Eichler's study tries to unravel the internal dynamics through which the will of the community is formed, thus 
orienting final decisions that will affect them forever. The focus is on those voices that are frequently excluded: vulnerable minority groups.

It is necessary to bear in mind that international human rights law arose and developed with an individualistic and not a collective perspective. There exist international and regional treaties focused on the rights of groups that require special protection (such as women, children and the elderly), but these are not implied in the rights of indigenous peoples. Attempts to cover this void were made in the Convention 169 and UNDRIP, as well as in international and regional jurisprudential development, by adapting the general human rights standards to the interests of indigenous peoples.

On the other hand, however, given the existence of a normative and jurisprudential spectrum on individual rights, it is necessary to pay attention to the perspectives of the community, particularly in relation to gender. An intercultural approach to the application of the law could avoid impositions from above, and generate dialogue to achieve a true reconciliation between individual and collective rights. A suggestive path to start with this reconciliation could be the empowerment of groups often excluded from the community, so that they can actively take part in decision-making processes. It is on this task, and on the dialogue between the State and the indigenous peoples, that this book reflects, discusses, and contributes.

The book is divided into six parts, including the introduction and final reflections by the author. Parts two and three present the general frame. After discussing the theoretical paradigms of individual and collective rights, a proposal is made to establish a meeting point, a "third perspective" that overcomes the classic dichotomy. This is done through a sub-group of rights that protect the demands existing within a collectivity, especially from minority groups.

This proposal is followed by an outline of the right to participation in international human rights law, again from the double perspective. From the individual perspective there is an impulse to exercise the right to participation in its various manifestations, but this right is not extended to the collective perspective, least of all when it comes to participation in matters related to the management of territories or the use of resources. In fact, one of the most sensitive aspects in this matter is the indigenous peoples' right to free, prior and informed consent. Despite the fact that the trend in international (and regional) human rights law is for indigenous peoples to have the possibility of deciding on state measures that put their survival at risk, states in practice reject all positions that could frustrate projects, mainly those of extractive nature. 
The fourth part analyses the extent to which subgroups, particularly women, have the possibility of exercising participation rights within the communities. This analysis focuses on the foundation of participation rights: the exercise of the right to self-determination, a right that has major implications for indigenous peoples because through its exercise they can defend their worldview or the way of life to which they aspire. The Bolivian case is exemplary in this respect, since the political, social and cultural movement that took place between 2007-2017 defined an indigenous philosophical thought known as Good Living. One important aspect of this definition is the principle of complementarity which gives women a prominent role of influence. It allows them to put their rights, inside as well as outside the community, on the agenda. The author reflects furthermore on intergenerational rights and the existence of generations in a community. The different generations, in particular children and elderly, are holders of rights that developed differently in international human rights law.

Eichler's work contributes in an interesting way to what is classically debated in academic circles: it invites us to reflect on a third way where individual and collective rights can meet each other. In this way, it offers a "reconciliatory framework" in the context of the exercise of participation rights, prior consultation and self-determination. Undoubtedly, this work of careful theoretical study should be taken seriously into account when putting into practice participatory processes that seek to achieve the decision of a community.

Amelia Alva-Arévalo Affiliated Researcher, Human Rights Centre, Ghent University 


\section{Copyright}

Deusto Journal of Human Rights / Revista Deusto de Derechos Humanos is an Open Access journal; which means that it is free for full and immediate access, reading, search, download, distribution, and reuse in any medium only for non-commercial purposes and in accordance with any applicable copyright legislation, without prior permission from the copyright holder (University of Deusto) or the author; provided the original work and publication source are properly cited (Issue number, year, pages and DOI if applicable) and any changes to the original are clearly indicated. Any other use of its content in any medium or format, now known or developed in the future, requires prior written permission of the copyright holder.

\section{Derechos de autoría}

Deusto Journal of Human Rights / Revista Deusto de Derechos Humanos es una revista de Acceso Abierto; lo que significa que es de libre acceso en su integridad inmediatamente después de la publicación de cada número. Se permite su lectura, la búsqueda, descarga, distribución y reutilización en cualquier tipo de soporte sólo para fines no comerciales y según lo previsto por la ley; sin la previa autorización de la Editorial (Universidad de Deusto) o la persona autora, siempre que la obra original sea debidamente citada (número, año, páginas y DOI si procede) y cualquier cambio en el original esté claramente indicado. Cualquier otro uso de su contenido en cualquier medio o formato, ahora conocido o desarrollado en el futuro, requiere el permiso previo por escrito de la persona titular de los derechos de autoría. 